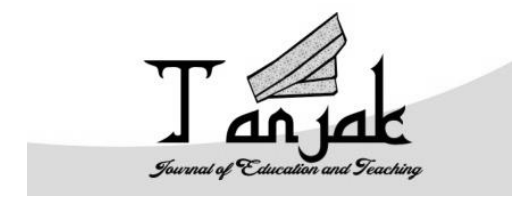

\author{
Tanjak: Journal of Education and Teaching \\ ISSN 2716-4098 (P) 2720-8966 (O) \\ Volume 1 Nomor 1, 2020
}

\title{
ANALISIS FAKTOR PENGAMBILAN KEPUTUSAN MAHASISWA UNTUK MEMILIH PROGRAM STUDI HUKUM EKONOMI SYARIAH DI STAIN SULTAN ABDURRAHMAN KEPULAUAN RIAU
}

\author{
Juni Aziwantoro ${ }^{1 *}$ \\ juni@stainkepri.ac.id
}

${ }^{1}$ STAIN Sultan Abdurrahman Kepulauan Riau

DOI: https://doi.org/10.35961/tanjak. v1i1.59

\begin{abstract}
Abstrak
Pendidikan tinggi baik itu PTU maupun PTKI tidak hanya fokus pada sumber pengetahuan, sumber pusat penelitian, dan sumber pusat pelayanan masyarakat saja, akan tetapi juga sebagai wujud dari korporat yang menghasilkan sumber dalam pengetahuan yang perlu bersaing untuk memastikan keberlangsungan hidup ini. Indrajit (2004) menjelaskan bahwa ada 5 macam dimensi arti di universitas atau institusi dalam bidang pendidikan, yaitu: (1) dimensi keilmiahan (berupa sains dan teknologi), (2) dimensi pendidikan (pendidikan tinggi berupa PTU/PTKI), (3) dimensi sosial (Kehidupan komunitas dalam masyarakat), (4) dimensi korporasi (unit pendidikan dan pengadministrasian) dan serta (5) dimensi etika/akhlak. Penelitian ini dilaksanakan di STAIN Sultan Abdurrahman Kepulauan Riau. Objek tertentu dalam penelitian yang dijalani ini yaitu mahasiswa Program Studi Hukum Ekonomi Syariah atau disingkat dengan HES. Penelitian dilakukan bertempat di Program Studi HES guna mengetahui faktor yang menjadi pengaruh keputusan para mahasiswa memilih Program Studi HES ini. Sedangkan waktu Penelitian yakni pada bulan Juli - Agustus 2019. Dari data yang didapat dalam hasil penelitian yang sudah dikerjakan, bahwa beberapa yang dapat dikemukakan bersama dalam penelitian tersebut ini adalah: 1) Pengaruh citra terhadap keputusan siswa untuk menempuh pendidikan di program studi HES, diperoleh thitung - 1.127 dengan tingkat signifikansi 0,264. Karena nilai signifikansi> 0,05, dapat disimpulkan bahwa variabel pada citra sama sekali tidak punya pengaruh dengan keputusan dari mahasiswa memilih Prodi HES, 2) Pengaruh biaya pendidikan terhadap keputusan siswa untuk belajar di program studi HES, diperoleh hitungan 4,671 dengan tingkat signifikansi dari 0,000. Karena nilai signifikansi $<0,05$, dapat disimpulkan bahwa biaya variabel mempengaruhi keputusan siswa. 3) Pengaruh prospek pada keputusan siswa untuk belajar di program studi HES, diperoleh jumlah 1.050 dengan tingkat signifikansi 0,297. Karena nilai
\end{abstract}

Tanjak: Jounal of Education and Teaching, Vol. 1, No. 1, 2020 
signifikansi> 0,05, dapat disimpulkan bahwa variabel prospek tidak berpengaruh terhadap keputusan siswa 4) Karena nilai signifikansi kurang dari 0,05, itu berarti bahwa gambar, biaya dan prospek program studi secara simultan mempengaruhi siswa keputusan untuk mengambil pendidikan di program studi Hukum Ekonomi. Syariah, jadi hipotesis keempat dalam penelitian ini diterima.

Kata kunci: Keputusan; Mahasiswa; Ekonomi

\begin{abstract}
Higher education is not only a knowledge center, research center, and community service center, but also as a corporate entity that produces knowledge that needs to compete to ensure survival. Indrajit (2004) explains that there are 5 dimensions of meaning in universities or institutions in the field of education, namely: (1) the scientific dimension (science and technology), (2) the educational dimension (higher education), (3) the social dimension (community life), (4) the corporate dimension (educational and administrative units) and (5) the ethical dimension. This research was conducted at STAIN Sultan Abdurrahman, Riau Islands. The object of this research is the students of Sharia Economic Law Study Program. The study was conducted at the Sharia Economic Law Study Program in order to find out the factors that influence the students' decision to choose the Sharia Economic Law Study Program. While the research time is in July August 2019. Based on data obtained from the results of the study, the conclusions that can be put forward in this study are: 1) The influence of the image on the decision of students to take education in the HES study program, obtained tcount - 1,127 with a significance level of 0.264 . Because the significance value $>0.05$, it can be concluded that the image variable does not affect student decisions, 2) The effect of educational costs on students' decision to study in the HES study program, obtained a count of 4,671 with a significance level of 0,000 . Because the significance value $<0.05$, it can be concluded that variable costs affect student decisions. 3) The effect of prospects on students' decision to study in the HES study program, obtained a total of 1,050 with a significance level of 0.297 . Because the significance value $>0.05$, it can be concluded that the prospect variable has no effect on student decisions 4) Because the significance value is less than 0.05, it means that the picture, cost and prospect of the study program simultaneously influence students' decision to take education in the study program Economic law. Sharia, so the fourth hypothesis in this study is accepted..
\end{abstract}

Keywords: Decisions; Students; Economics

\title{
Pendahuluan
}

Pada saat dunia modern ini yang kita hadapi merupakan tantangan globalisasi yang menyebabkan berubah di setiap elemen dan bidang. Perubahan ini menuntut banyak negara-negara untuk melakukan sebuah reformasi khusus, terutama dalam bidang perekonomian. Globalisasi sendiri telah mengajak suatu perusahaan untuk siap menghadapi persaingan secara global dan secara drastis mengubah pola strategi yang dijalankan perusahaan tersebut, terutama strategi pemasaran suatu bisnis dan produk suatu bisnis. Setiap perusahaan tentunya bersaing untuk strategi pemasarannya untuk bertahan dalam bisnis yang dijalankan. Persaingan atau Kompetisi yang dijalankan ini menuntut tingkat kreativiti ole setiap perusahaan untuk sempurna dan mengembangkan produk dan hasil yang terbaru.

Dunia pendidikan mengalami perubahan dalam citra/panorama. Perubahan tersebut dimaksud meliputi bentuk perubahan paradigma, perubahan dalam manajemen, perubahan dalam kompetisi, dan lain sebagainya. Perubahan dalam paradigma terutama dipicu oleh perkembangan dalam teknologi informasi sehingga e-learning, e-universitas dan sejenisnya mulai banyak dibahas saat ini dan selalu 
dicari. Perubahan dalam manajemen melibatkan penyedia pendidikan tinggi, baik pemerintah maupun sektor swasta. Perdebatan tentang Entitas Hukum dan Entitas Pendidikan Hukum sering menjadi wacana. Memulai universitas asing juga telah membantu meningkatkan kompetisi di negara ini. Persaingan, seperti yang dialami oleh perusahaan nirlaba, termasuk persaingan di bidang kualitas, harga, dan layanan. Pendidikan tinggi sebagai entitas nirlaba, menghadapi hal yang sama. Untuk semua manajemen seperti itu, pengetahuan dan keterampilan manajemen diperlukan, yaitu manajemen dalam universitas yang ada.

Pendidikan tinggi/universitas/institut/sekolah tinggi tidak hanya mengembangkan dalam bentuk pusat pengetahuan, bentuk penelitian, dan bentuk pelayanan masyarakat, tetapi juga sebagai entitas didalam korporat yang menghasilkan pengetahuan yang perlu bersaing untuk memastikan kelangsungan hidup. Indrajit (2004) menjelaskan bahwa ada 5 dimensi makna di universitas atau institusi di bidang pendidikan, yaitu: (1) dimensi keilmiahan (sains dan teknologi), (2) dimensi kependidikan (pendidikan tinggi), (3) dimensi kesosialan (kehidupan komunitas), (4) dimensi korporasi (unit kependidikan dan administrasi) dan (5) dimensi etika.

Demikian juga dengan Program Studi Hukum Ekonomi Syariah, Jurusan Syariah, Sekolah Tinggi Agama Islam Negeri Sultan Abdurrahman, Kepulauan Riau.

Berangkat dari penjelasn yang dipaparkan di atas, masalah penelitian dapat dirumuskan sebagai "Analisis Faktor Pengambilan Keputusan Mahasiswa untuk Memilih Program Studi Hukum Ekonomi Syariah di STAIN Sultan Abdurrahman Kepulauan Riau".

\section{Istilah pengambilan Keputusan}

\section{a. Pengertian Pengambilan Keputusan}

Istilah pengambilan/pembuat suatu keputusan adalah hal penting yang mendasar dalam kehidupan seseorang. pengambilan/pembuat suatu keputusan atau pengambilan keputusan adalah cara yang terjadi dalam suatu sistem, bahkan jika itu adalah keputusan atau sebagai bentuk keinginan pribadi, bahkan jika itu melibatkan masalah pribadi . Menurut Stoner, dikatakan bahwa pengambilan/pembuat suatu keputusan adalah proses memilih tindakan sebagai cara untuk menyelesaikan masalah yang ada . Sementara itu, dalam pendapat lain, pengambilan keputusan menurut Siagian adalah metode pendekatan sistematis untuk sifat sebenarnya dari suatu masalah, mengumpulkan data-data serta fakta-fakta, menentukan kesiapandari alternatif yang diperoleh dan mengambil tindakan sesuai dengan perhitungan yang terbanyak. tindakan yang sesuai dengan konsep. Definisi yang dinyatakan oleh Siagian di atas menunjukkan lima hal yang berkaitan dengan pengambilan keputusan, iaitu (1) dalam proses pengambilan keputusan tidak ada yang dianggap tidak sengaja, (2) pengambilan keputusan tidak dilakukan sewenang-wenang karena pendekatan pengambilan keputusan harus didasarkan pada sistematis tertentu (3) sebelum masalah dapat diselesaikan, sifat masalah mestilah jelas dan terkenal. (4) penyelesaian masalah tidak dilakukan oleh "bimbingan" atau dengan menanamkan kejuruteraan, tetapi harus berdasarkan fakta dan data yang dikumpulkan secara sistematik, diproses dengan baik dan disimpan secara berkala supaya fakta dan data dapat dipercaya dan terkini.

Berdasarkan penerangan/uraian pendapat di atas, maka dapat disimpulkan bahwa pengambilan keputusan/membuat keputusan adalah proses/metode/cara pemilihan terbaik dari beberapa alternatif yang akan digunakan sebagai cara untuk menyelesaikan masalah dengan mencapai tujuan yang diinginkan. 


\section{b. Dasar-dasar Pengambilan Keputusan/membuat keputusan}

Dasar yang dipakai dalam membuat pemilihan/pengambilan keputusan bervariasi, bergantung kepada masalah yang dihadapi oleh setiap elemen. George R. Terry menyebutkan asas-asas membuat pemilihan / pengambilan keputusan seperti berikut :

1) Intuisi

Membuat pemilihan/Pengambilan keputusan berdasarkan sebuah perasaan atau diistilahkan memiliki sifat yang subyektif, sehingga mudah terpengaruh.

2) Pengalaman

Membuat pemilihan/Pengambilan keputusan didasarkan pada pengalaman yang memiliki manfaat bagi pengetahuan praktis, karena pengalaman yang dimiliki oleh seseorang dapat menentukan/prediksi keadaan sesuatu, dapat menghitung kelebihan dan kekurangan dari keputusan yang akan dihasilkan tersebut.

3) Fakta

Membuat pemilihan/Pengambilan keputusan berdasarkan fakta dapat memberikan keputusan yang sangat baik, solid, dan matang. Melalui adanya fakta, tingkat pada kepercayaan dalam membuat pemilihan/ pengambilan keputusan dapat diterima lebih tinggi, sehingga orang dapat menerima keputusan yang dibuat secara sukarela.

4) Tanggung Jawab/Wewenang

Membuat pemilihan/ Pengambilan keputusan berdasarkan wewenang biasanya dibuat oleh pemimpin bawahan atau orang-orang yang posisinya lebih tinggi dari mereka yang berpangkat dibawah pimpinan.

5) Rasional/masuk akal

Dalam membuat keputusan berasaskan rasional (masuk akal), keputusan yang dihasilkan adalah objektif, logik, lebih jelas/transparan, untuk memaksimumkan hasil atau nilai dalam batas ketentuan supaya mereka boleh dikatakan dekat dengan kebenaran atau mengikut apa yang dikehendaki.

\section{c. Faktor Pengambilan Keputusan}

Terdapat beberapa faktor-faktor yang mempengaruhi pada membuat pemiluhan/pengambilan keputusan. Menurut Hasan faktor tersebut diantaranya :

1) Position/Posisi

Dalam rangka pembuatan keputusan seseorang dapat dilihat pada posisi dan tingkat posisi tersebut.

2) Problem/Masalah

Masalah atau probelm itulah yang menjadi hambatan dalam pencapaian suatu tujuan, yang merupakan penyelewengan dari apa yang diharapkan, dirancang, atau dikehendaki dan mesti diselesaikan. Masalah tidak selalu dapat langsung dikenali, beberapa memerlukan analisis dan bahkan penelitian terpisah.

3) Situasi

Suatu situasi adalah faktor keseluruhan dalam suatu situasi, yang terkait satu sama lain, dan yang bersama-sama memiliki pengaruh pada kita dan apa yang ingin kita lakukan.

4) Ketentuan

Kondisi adalah semua faktor yang bersama-sama menentukan motilitas, kekuatan akting, atau kemampuan kita. Sebagian besar faktor ini adalah sumber daya.

5) Tujuan 
Sasaran yang ingin dicapai, baik sasaran individu, tujuan satuan (kesatuan), sasaran organisasi, dan sasaran bisnis yang umumnya ditentukan. Oleh karena itu Tujuan yang ditetapkan tersebut dalam pengambilan keputusan bersifat menengah dan atau objektif.

\section{d. Langkah (Proses) Pengambilan Keputusan}

Menurut Sir Francis Bacon proses pengambilan keputusan terdiri dari enam tahap yaitu :

1) Merumuskan / Menentukan Masalah

Ini adalah upaya untuk menemukan masalah sebenarnya.

2) Pengumpulan Informasi yang Relevan

Merupakan pencarian faktor-faktor yang mungkin terjadi sehingga mereka dapat mengetahui penyebab masalahnya.

3) Menemukan Tindakan Alternatif

Adalah pencarian kemungkinan yang dapat diambil berdasarkan data dan masalah yang ada.

4) Analisis Alternatif

Merupakan analisis dari setiap alternatif sesuai dengan kriteria tertentu yang bersifat kualitatif atau kuantitatif.

5) Memilih Alternatif Terbaik

Seleksi alternatif terbaik dibuat berdasarkan kriteria dan skala prioritas tertentu.

6) Melaksanakan keputusan dan mengevaluasi hasil

Ini adalah tahap implementasi dan tindakan. Secara umum, tindakan ini dituangkan ke dalam rencana aksi. Hasil evaluasi memberikan masukan / umpan balik yang bermanfaat untuk meningkatkan keputusan atau mengubah tujuan awal karena perubahan telah dilakukan.

Berdasarkan hasil pada penjelasan di atas, dengan indikator yang digunakan untuk mengukur keputusan mahasiswa dalam penelitian ini adalah mengidentifikasi masalah yang ada, mengumpulkan beberapa informasi yang sesuai/relevan, mencari cara/metode alternatif, menganalisis alternatif itu, memilih suatu alternatif terbaik, menerapkan keputusan/pemilihan dan mengevaluasi hasil tersebut.

\section{Biaya Pendidikan}

Apa yang dikatakan mengenai cost (biaya) pendidikan adalah salah satu komponen terpenting input instrumental dalam pentadbiran pendidikan . Biaya dalam pengertian ini memiliki ruang lingkup yang luas, yaitu semua jenis pengeluaran terkait dengan pengiriman pendidikan, baik dalam bentuk uang maupun barang dan tenaga kerja (yang dapat dinilai dalam uang). Selain itu, menurut Wijaya, biaya didefinisikan sebagai semua jenis biaya yang dikeluarkan untuk melaksanakan pendidikan. Sedangkan pendapat lain yang disebut sebagai biata (cost) adalah semua cost yang ditanggung oleh par mahasiswa untuk mendapatkan perkhidmatan/layanan pendidikan yang ditawarkan oleh institusi perguruan tinggi

Biaya pendidikan termasuk Sumbangan Pengembangan Pendidikan (SPP), Dana dan Fasilitas Kesejahteraan Mahasiswa (DKM) per semester, dana untuk asrama (khusus untuk siswa yang tinggal di asrama) per bulan termasuk biaya makanan dan transportasi, dan biaya lainnya seperti keanggotaan perpustakaan, komputer laboratorium kesehatan dan lainnya. Ada perbedaan dalam biaya pendidikan di setiap institusi tersier, menurut Rambat Lupiyoadi \& A. Hamdani, sebuah institusi tersier menggunakan biaya kuliah yang berbeda untuk setiap siswa dan program, termasuk: 
a. Berdasarkan program studi; contoh: ilmu sosial, ilmu teknik, ilmu kebahasaan dan ilmu hukum dan ilmu politik

b. Berdasarkan tingkat siswa; Contoh: Mahasiswa s1 berbeda dengan mahasiswa s2 dan s3, di mana biaya s2 dan s3 lebih mahal dari s1

c. Berdasarkan beban kredit siswa, beban SKS mahasiswa S1 lebih banyak dari beban SKS mahasiswa S2

d. Berdasarkan jenis program siswa; misalnya: program S1/D4/D3/D2 dengan gelar sarjana atau nongelar / sarjana muda / diploma.

Dalam penelitian ini, biaya pendidikan adalah keseluruhan pengorbanan finansial yang ditimbulkan oleh konsumen (orang tua siswa atau siswa) untuk tujuan mengambil pendidikan dari awal hingga akhir pendidikan. Biaya ini termasuk biaya pendaftaran, biaya hidup dan biaya kuliah yang dikeluarkan untuk tujuan pemulihan. Indikator biaya pendidikan dalam penelitian ini adalah biaya kuliah / UKT, biaya buku, beasiswa, dan biaya praktik.

\section{Citra Prodi}

\section{a. Pengertian Citra Prodi}

Citra adalah kesan yang diperoleh seseorang berdasan mereka akan fakta atau kenyataan. Dalam Kamus Besar Bahasa Indonesia (KBBI), pengertian citra adalah: (1), gambarkan penampilan, gambar; (2) gambar memiliki banyak orang tentang seseorang, perusahaan, organisasi, atau produk; (3) kesan mental atau gambar visual yang dihasilkan oleh, ungkapan atau kalimat tersebut, dan merupakan elemen dasar yang khas dalam prosa dan puisi; (4) data atau informasi dari potret udara untuk evaluasi.

Pendapat lain dikatakan bahwa ciitra adalah kesan yang berasal dari pemahaman realitas. Pemahaman itu sendiri muncul karena maklumat. Bahwa Nova mengungkapkan citra adalah persepsi nyata dari suatu objek yang dibentuk dengan mengolah informasi terbaru dari beberapa sumber setiap saat.

Sebagai hasil yang disampaikan oleh para ahli pada, kita dapat menyimpulkan bahwa citra tersebut adalah gambar atau kesan yang diperoleh dari lingkungan atau pihak lain sebagai hasil dari pengalaman dan pengetahuannya tentang suatu objek. Citra yang baik dimaksudkan untuk menjaga organisasi agar tetap hidup dan orang-orang di dalamnya dapat terus mengembangkan kreativitas.

\section{b. Proses Pembentukan Citra}

dibentuk berdasarkan pengetahuan dan maklumat yang diterima oleh seseorang. Komunikasi tidak langsung menyebabkan tingkah laku tertentu tetapi cenderung mempengaruhi cara kita mengawal citra alam sekitar kita. Berikut adalah model untuk membentuk gambaran pengalaman mengenai rangsangan: 


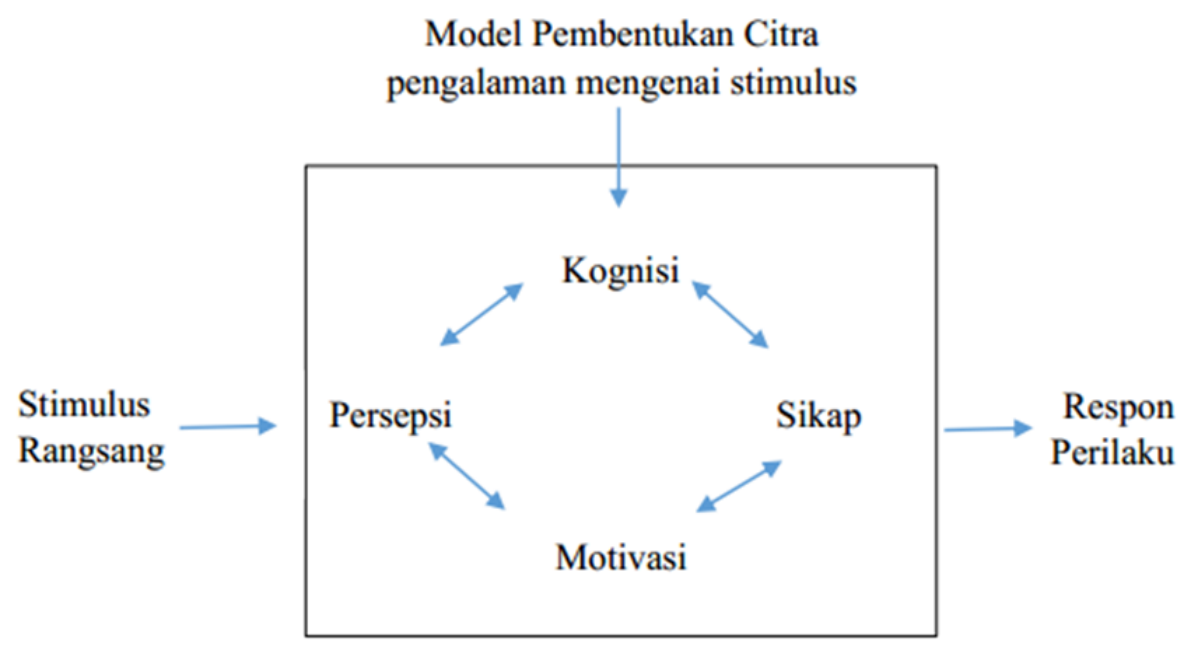

Sumber: Dasar-Dasar Public Relations (Soleh Soemirat dan Elvinaro. 2008)

Gambar 1. Model Pembentukan Citra pengalaman mengenai stimulus

Model dalam kaidah gambar ini menunjukkan bagaimana rangsangan eksternal / eksternal diatur dan memengaruhi tanggapan. Stimulus (rangsangan) yang diberikan kepada individu dapat diterima atau ditolak. Jika rangsangan ditolak maka proses selanjutnya tidak akan berhasil, ini menunjukkan stimulus tidak efektif dalam mempengaruhi individu karena tidak ada perhatian dari individu tersebut. Sebaliknya, jika stimulus diterima oleh seseorang, itu berarti ada komunikasi dan perhatian dari organisme sehingga proses selanjutnya dapat dilanjutkan.

Keempat komponen persepsi-kognisi-motivasi-sikap ditafsirkan sebagai gambar stimulan individu. Jika stimulus mendapat perhatian, individu akan mencoba memahami stimulasi. Persepsi didefinisikan sebagai hasil mengamati unsur-unsur lingkungan yang terkait dengan proses makna, dengan kata lain, individu akan memberikan makna pada stimulus berdasarkan pengalamannya tentang stimulus. Kemampuan memahami inilah yang dapat melanjutkan proses pembentukan gambar. Persepsi atau pandangan individu akan positif jika informasi yang diberikan oleh stimulus memenuhi kognisi individu.

Kognisi adalah kepercayaan individu dalam rangsangan. Kepercayaan ini akan timbul jika individu memahami rangsangan tersebut, sehingga individu itu harus diberikan informasi yang cukup yang dapat mempengaruhi perkembangan kognisi. Motivasi dan sikap yang ada akan menggalakkan respons seperti yang dikehendaki oleh pemberi. Motif adalah syarat dalam seseorang yang mendorong keinginan individu untuk menjalankan aktiviti tertentu untuk mencapai tujuan. Sedangkan Sikap adalah kecenderungan untuk bertindak, melihat, berfikir, dan merasa dalam objek, idea, situasi atau nilai. Sikap bukan tingkah laku tetapi kecenderungan untuk bertindak dengan cara tertentu.

Sikap memiliki kekuatan yang motivasi. Sikap menjadi penentu dari orang yang memiliki pro atau kontra tentang sesuatu, menentukan apa yang mereka sukai, harapkan, dan inginkan. Sikap mengandung aspek evaluatif, artinya mengandung nilai-nilai menyenangkan atau tidak menyenangkan. Sikap ini juga bisa diperkuat atau diubah. Proses pembentukan citra pada akhirnya akan menghasilkan 
sikap, pendapat, respons atau perilaku tertentu. Berdasarkan penjelasan dan keterangan di atas, indikator yang digunakan untuk mengukur variabel citra program studi adalah kualitas dosen (SDM), layanan program studi, popularitas program studi.

\section{Fasilitas Pendidikan}

Fasilitas adalah semua hal yang memfasilitasi dan memfasilitasi suatu kegiatan. Fasilitas pendidikan di sekolah dapat dikelompokkan menjadi dua, yaitu fasilitas pendidikan dan infrastruktur pendidikan. Pendapat lain dikatakan bahwa pendidikan adalah alat, bahan dan furnitur yang secara langsung digunakan dalam proses pendidikan di sekolah, sedangkan infrastruktur pendidikan adalah semua alat utama yang secara tidak langsung mendukung pelaksanaan proses pendidikan dilingkungan sekolah.

Sejalan dengan pendapat diatas, menjelaskan fasilitas pendidikan adalah peralatan dan peralatan yang secara langsung digunakan dan mendukung proses pendidikan, terutama pengajaran dan pembelajaran, seperti bangunan, ruang kelas, kursi meja, dan alat pengajaran dan media, seperti untuk yang dimaksud dengan infrastruktur pendidikan adalah fasilitas yang tidak secara langsung mendukung jalannya proses pendidikan atau pengajaran, seperti halaman, sekolah, jalan menuju sekolah, tetapi digunakan secara langsung untuk proses belajar mengajar, seperti taman sekolah untuk pengajaran biologi, lapangan sekolah sebagai lapangan serta tempat olahraga, komponen-komponen ini adalah fasilitas pendidikan .

Pendapat lain juga menjelaskan bahwa Kemudahan pendidikan adalah peralatan dan peralatan yang digunakan secara langsung dan untuk menyokong proses pendidikan, terutamanya dalam proses pengajaran dan pembelajaran, seperti bangunan, ruang kelas, meja, kursi, serta alat dan media pengajaran. Apa yang dimaksudkan dengan infrastruktur pendidikan atau pengajaran dalam proses pembelajaran, seperti alasan sekolah, taman sekolah, dan jalan yang menuju sekolah .

Dari pemahaman tersebut, maka disimpulkan bahwa fasilitas pendidikan adalah semua kemudahan dan infrastruktur yang tersedia untuk memfasilitasi dan mendukung kegiatan belajar. Kemudahan pendidikan yang mencukupi dan lengkap diperlukan oleh institusi pendidikan untuk menyokong proses aktivitas pengajaran dan pembelajaran, baik di peringkat pendidikan dasar maupun sampai pada tingkat universitas. Pelajar/mahasiswa akan berasa senang jika semua kemudahan yang diperlukan dan boleh digunakan sebagai fungsi yang baik.

Klasifikasi infrastruktur dalam pendidikan terdapat dua bentuk. Pertama, infrastruktur pendidikan yang secara langsung digunakan untuk proses belajar mengajar, seperti kelas teori, kelas perpustakaan, kelas praktik keterampilan, dan kelas laboratorium. Kedua, infrastruktur sekolah tempat keberadaannya tidak digunakan untuk pengajaran dan pembelajaran, tetapi secara langsung mendukung proses belajar mengajar. Misalnya ruang kantor, tanah dan jalan menuju sekolah, toilet, UKS, ruang dosen atu guru, ruang kepala sekolah/ruang pimpinan, dan tempat fasilitas parkir .

Berdasarkan pemahaman fasilitas dalam pendidikan dan kelas-kelas pada institusi pendidikan di atas, indikator yang digunakan untuk mengukur fasilitas pendidikan dalam penelitian ini adalah ruang kelas, ruang perpustakaan, dan ruang laboratorium. 


\section{Prospek Prodi}

Menurut Kamus Besar Bahasa Indonesia (KBBI), memahami prospek adalah kemungkinan dan harapan. Dalam definisi ringkas, prospek boleh ditafsirkan sebagai perkara yang mungkin berlaku dalam sesuatu perkara yang berpotensi menyebabkan kesan tertentu. Sedangkan pekerjaan mempunyai makna kegiatan melakukan sesuatu atau dilakukan, kerja adalah suatu kegiatan yang dilakukan oleh seseorang untuk melakukan atau menghasilkan cara untuk memenuhi kebutuhan barang dan jasa dengan mendapatkan hadiah atau upah. Maka apa yang dimaksudkan dengan prospek prodi adalah ketersediaan peluang pekerjaan yang dapat dilakukan untuk lulusan untuk menghasilkan barang atau jasa dan mendapat ganti rugi berupa gaji atau upah.

\section{Metode Penelitian}

Penelitian ini dilakukan di STAIN Sultan Abdurrahman, Kepulauan Riau. Objek penelitian ini adalah mahasiswa Program Studi Hukum Ekonomi Syariah. Penelitian dilakukan di Program Studi Hukum Ekonomi Syariah untuk mengetahui faktor-faktor yang mempengaruhi keputusan siswa untuk memilih Program Studi Hukum Ekonomi Syariah. Sedangkan waktu penelitian adalah Juli - Agustus 2019.

Dalam penelitian ini, penulis menggunakan jenis korelasinya. Penelitian ini sering disebut dengan penelitian kausal, untuk mengetahui hubungan antara variabel independen dengan variabel dependen. Penelitian ini dibangun dengan teori yang matang, yang berfungsi untuk mengetahui, memprediksi dan mengendalikan suatu fenomena.

Kajian ini menggunakan pendekatan kuantitatif. Kaedah tinjauan telah dipilih sebagai sumber data utama. Kaedah tinjauan menumpukan pada mengumpul data responden yang mempunyai maklumat tertentu supaya ia membolehkan penyelidik menyelesaikan masalah. Pengumpulan data dilakukan dengan menggunakan kuesioner atau instrumen kuesioner. Berdasarkan tahap eksplorasi, itu dikelaskan sebagai penelitian atau penelitian asosiatif, yang merupakan penelitian untuk menentukan hubungan sebab akibat (kausalitas). Hubungan atau pengaruh variabel independen (X) terhadap variabel (Y).

\section{Hasil dan Pembahasan}

\section{Kerangka Penelitian}

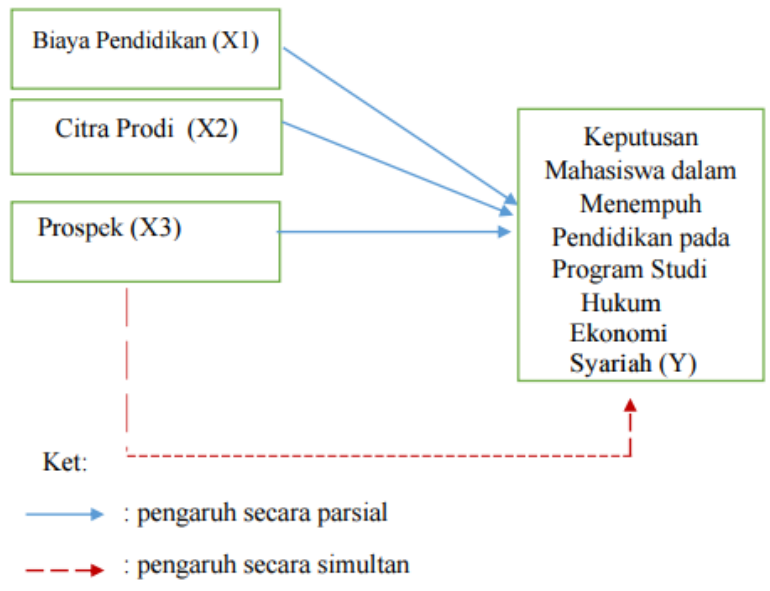

Tanjak: Jounal of Education and Teaching, Vol. 1, No. 1, 2020 


\section{Hasil Uji Validitas dan Reabilitas}

Dalam penyelidikan kuantitatif, terjadi uji validitas dan uji reliabilitas yang digunakan untuk menentukan apakah ukuran instrumen yang baik akan digunakan dalam hasil ini. Biasanya, tes ini dilakukan pada penelitian yang menggunakan alat/instrumen kuesioner. Dalam penelitian ini, alat/kuesioner akan dibagikan sebanyak 30 orang. Berikut ini adalah deskripsi hasil uji validitas dan reliabilitas.

\section{a. Uji Validitas dan Reliabilitas Citra Prodi (X1)}

Berdasarkan tabel tersebut, diketahui bahawa terdapat 10 butir soal dinyatakan Valid. Sehingga untuk mengetahui pengaruh faktor citra prodi terhadap keputusan mahasiswa memilih Prodi Hukum Ekonomi Syariah digunakan 10 butir soal yang telah dinyatakan valid. Sedangkan hasil uji reabilitas untuk variabel faktor citra prodi (X1) yaitu sebesar 0,799. Dinyatakan reliabel karena r11 > 0,6 atau $0,799>0,6$ yang dinyatakan Reliable.

\section{b. Uji Validitas dan Reliabilitas Biaya (X2)}

Berdasarkan tabel tersebut, diketahui bahawa terdapat 7 butir soal dinyatakan Valid. Sehingga untuk mengetahui pengaruh faktor citra prodi terhadap keputusan mahasiswa memilih Prodi Hukum Ekonomi Syariah digunakan 10 butir soal yang telah dinyatakan valid. Sedangkan hasil uji reabilitas untuk variabel faktor biaya (X2) yaitu sebesar 0,792. Dinyatakan reliabel karena r11 > 0,6 atau 0,792> 0,6 yang dinyatakan Reliable.

\section{c. Uji Validitas dan Reliabilitas Prospek (X3)}

Berdasarkan tabel tersebut, diketahui bahawa terdapat 10 butir soal dinyatakan Valid. Sehingga untuk mengetahui pengaruh faktor citra prodi terhadap keputusan mahasiswa memilih Prodi Hukum Ekonomi Syariah digunakan 10 butir soal yang telah dinyatakan valid. Sedangkan hasil uji reabilitas untuk variabel faktor Prospek (X3) yaitu sebesar 0789. Dinyatakan reliabel karena r11 > 0,6 atau 0,789 $>0,6$ yang dinyatakan Reliable.

\section{d. Uji Validitas dan Reliabilitas Keputusan (Y)}

Berdasarkan tabel tersebut, diketahui bahawa terdapat 7 butir soal dinyatakan Valid. Sehingga untuk mengetahui pengaruh faktor citra prodi terhadap keputusan mahasiswa memilih Prodi Hukum Ekonomi Syariah digunakan 10 butir soal yang telah dinyatakan valid. Sedangkan hasil uji reabilitas untuk variabel keputusan memilih (Y) yaitu sebesar 0,763. Dinyatakan reliabel karena $\mathrm{r} 11>0,6$ atau $0,763>0,6$ yang dinyatakan Reliable.

\section{Uji Analisis Prasyarat}

Sebelum melakukan pengujian pada penelitian ini, terlebih dahulu menguji data analisis prasyarat. Uji analisis prasyarat bertujuan untuk mengetahui data yang dikumpul layak untuk dianalisis dengan teknik statistik. uji prasyarat ini meliputi uji normalitas, uji linieritas, uji multikolinieritas, dan uji homoscedastisitas.

\section{a. Uji Asumsi Klasik}

1) Uji Normalitas

Uji normalitas ini menggunakan uji Kolmogorov-Smirnov. Data uji normalitas yang dilakukan menunjukkan bahwa setiap variabel dalam penelitian ini berdistribusi normal. Ini ditunjukkan oleh nilai Asymp Sig lebih dari 0,05. Hasil tes normal ditunjukkan pada tabel berikut: 


\section{One-Sample Kolmogorov-Smirnov Test}

\begin{tabular}{llr} 
& & $\begin{array}{r}\text { Unstandardized } \\
\text { Residual }\end{array}$ \\
\hline Normal Parameters & & 70 \\
\hline & Mean &, 0000000 \\
\cline { 2 - 3 } & Std. Deviation &, 090 \\
\hline Most Extreme Differences & Absolute &, 059 \\
\cline { 2 - 3 } & Positive &,- 090 \\
\cline { 2 - 3 } & Negative &, 090 \\
\hline Test Statistic & &, 200 c,d \\
\hline Asymp. Sig. (2-tailed) & & \\
\hline a. Test distribution is Normal. & \\
b. Calculated from data. & \\
c. Lilliefors Significance Correction. \\
d. This is a lower bound of the true significance.
\end{tabular}

Dari hasil diatas, besarnya nilai kolmogorov-smirnov adalah dengan signifikansi sebesar 0.200. Karena nilai

signifikansi kolmogorov-smirnov sebesar $0.200>0,05$ maka dapat disimpulkan bahwa data berdistribusi normal.

2) Uji Linieritas

\begin{tabular}{|l|l|l|l|l|l|}
\hline Variabel Y & Variabel X & F hitung & F tabel & Sig & Keterangan \\
\hline \multirow{2}{*}{$\begin{array}{l}\text { Keputusan } \\
\text { Pemilihan }\end{array}$} & Citra & 0,757 & 2,74 & 0,680 & Linier \\
\cline { 2 - 6 } & Biaya & 2,666 & 2,74 & 0,014 & Linier \\
\cline { 2 - 6 } & Prospek & 0,610 & 2,74 & 0,748 & Linier \\
\hline
\end{tabular}

a) Berdasarkan hasil linearitas variabel Gambar (X1) pada keputusan siswa untuk belajar di program studi hukum Ekonomi Syariah (Y), nilai Fcount 0,757 <Ftt 2,74 diperoleh. Nilai $\mathrm{p}=0$ 0,680 lebih besar dari $0,05(\mathrm{P}>0,05)$, dengan demikian dapat disimpulkan bahwa hubungan antara citra dan keputusan siswa untuk menempuh pendidikan di program studi Hukum Ekonomi Syariah adalah linier.

b) Berdasarkan hasil uji linearitas dari variabel Biaya (X2) pada keputusan siswa untuk belajar di program studi hukum Ekonomi Syariah (Y), diperoleh nilai Fhitung 2,666 <Ft 2,74. Nilai $p=0,014$ lebih besar dari 0,05 (P>0,05), sehingga dapat disimpulkan bahwa hubungan antara biaya pendidikan dan keputusan siswa untuk menempuh pendidikan dalam program studi hukum Ekonomi Syariah adalah linier.

c) Berdasarkan hasil uji linieritas variabel Prospek (X3) terhadap keputusan siswa untuk belajar di program studi hukum Ekonomi Syariah (Y), diperoleh nilai Fhitung sebesar 0,610<Ft 2,74. Nilai p 
$=0,748$ lebih besar dari 0,05 ( $\mathrm{P}>0,05)$, sehingga dapat disimpulkan bahwa hubungan antara prospek dan keputusan siswa yang mengambil pendidikan di program studi Hukum Syariah Ekonomi adalah linier.

3) Uji Multikolonieritas

Tes multikolinieritas dilakukan untuk mendapatkan gambara apakah ada hubungan yang sangat kuat/sempurna antara variabel X. Berikut ini adalah ringkasan hasil uji multikolinieritas untuk 4 variabel bebas:

\begin{tabular}{|l|l|}
\hline Variable & Nilai VIF \\
\hline Citra & 1,087 \\
\hline Biaya & 1,079 \\
\hline Prospek & 1,011 \\
\hline
\end{tabular}

Berdasarkan hasil analisis pada tabel di atas, terlihat bahwa masing-masing variabel bebas dalam penelitian ini, yaitu, citra program studi, biaya, dan prospek program studi memiliki nilai VIF kurang dari 10. Sehingga dapat disimpulkan bahwa tidak ada gejala multikolinieritas.

a) Uji Homosedastisitas

Uji homosedastisitas digunakan untuk menentukan kesamaan varians kesalahan untuk setiap nilai pada variable $\mathrm{X}$. Uji homoscedasticity dalam penelitian ini menggunakan uji Park jika uji $\mathrm{F}$ signifikan (sig <0,05) maka itu menunjukkan terjadinya heterosedastisitas sedangkan jika sig F lebih dari atau sama dengan 0,05 maka heteroskedastisitas tidak terjadi. Hasil dari pengujian homoscedasticity adalah sebagai berikut:

\begin{tabular}{|c|c|c|c|c|c|c|}
\hline \multicolumn{7}{|c|}{ ANOVA $^{a}$} \\
\hline Model & & Sum of Squares & $\mathrm{df}$ & Mean Square & $\mathrm{F}$ & Sig. \\
\hline \multirow[t]{3}{*}{1} & Regression & 6,823 & 3 & 2,274 & 1,189 &, $321^{\mathrm{b}}$ \\
\hline & Residual & 126,217 & 66 & 1,912 & & \\
\hline & Total & 133,040 & 69 & & & \\
\hline
\end{tabular}

a. Dependent Variable: RES2

b. Predictors: (Constant), Prospek, Biaya, Citra Prodi

Berdasarkan keputusan analisis di atas menunjukkan bahawa nilai $\mathrm{F}$ yang ditemui ialah 1,189 dengan sig sebanyak 0.321. Kerena sig lebih besar daripada 0.05, dapat disimpulkan bahawa heteroscedasticity tidak berlaku, sehingga keperluan regresi dipenuhi.

b) Uji Hipotesis Penelitian

i) Tes Koefisien Determinasi (R2)

Pengujian ini bertujuan untuk membuktikan pengaruh citra, biaya, dan prospek program studi terhadap keputusan mahasiswa untuk belajar di program studi hukum Ekonomi Syariah. Dalam mengungkapkan hipotesis ini, maka peneliti menggunakan teknik regresi linier berganda dengan bantuan program SPSS 25.0 for windows. Ini adalah ringkasan dari hasil pengujian hipotesis: 


\begin{tabular}{l|r|r|r|r} 
& & \multicolumn{2}{c}{ Model Summary } \\
& & & $\begin{array}{c}\text { Adjusted R } \\
\text { Square }\end{array}$ & $\begin{array}{c}\text { Std. Error of the } \\
\text { Estimate }\end{array}$ \\
\hline Model & R & R Square & \multicolumn{1}{c}{ Squ } \\
\hline 1 &, $506^{\mathrm{a}}$ &, 256 &, 222 & 2,34032 \\
\hline
\end{tabular}

a. Predictors: (Constant), Prospek, Biaya, Citra

Dari tabel tersebut aıketanuı Danwa nası adjustea $\kappa$ square adaın $u, \angle \supset 0$ atau $\angle \supset, 0 \%$. Hal ini menunjukan bahwa keputusan mahasiswa dalam memilih Prodi Hukum Ekonomi Syariah dapat dijelaskan oleh variabel faktor citra, biaya, dan prospek lapangan kerja sebesar 25,6\%, sedangkan sisanya $74,4 \%(100 \%-49,6 \%)$ dijelaskan oleh faktor-faktor lain yang tidak diteliti dalam penelitian ini.

ii) Hasil Uji Signifikansi Koefisien Regresi Secara Parsial (Uji t)

\begin{tabular}{|c|c|c|c|c|c|c|}
\hline \multicolumn{7}{|c|}{ Coefficients $^{a}$} \\
\hline \multirow{3}{*}{\multicolumn{2}{|c|}{ Model }} & \multirow{2}{*}{\multicolumn{2}{|c|}{ Unstandardized Coefficients }} & \multirow{3}{*}{$\begin{array}{c}\text { Standardized } \\
\text { Coefficients } \\
\text { Beta } \\
\end{array}$} & \multirow[b]{3}{*}{$\mathrm{t}$} & \multirow[b]{3}{*}{ Sig. } \\
\hline & & & & & & \\
\hline & & $\mathrm{B}$ & Std. Error & & & \\
\hline & (Constant) & 10,981 & 4,290 & & 2,560 &, 013 \\
\hline & Citra &,- 083 &, 074 &,- 125 & $-1,127$ & ,264 \\
\hline & Biaya &, 443 & ,095 &, 515 & 4,671 &, 000 \\
\hline & Prospek & ,075 &, 072 &, 112 & 1,050 & ,297 \\
\hline
\end{tabular}

a. Dependent Variable: Keputusan

iii) Hipotesis Citra

Berdasarkan hasil keputusan hitungan secara parsial bahwa, pengaruh citra terhadap keputusan siswa menempuh pendidikan di program studi HES, diperoleh thitung -1,127 dengan taraf signifikansi 0,264. Oleh karena nilai signifikansi> 0,05, dapat disimpulkan bahwa variabel gambar tidak berpengaruh terhadap keputusan siswa, sehingga hipotesis pertama yang menyatakan "Citra memiliki pengaruh positif terhadap keputusan siswa untuk belajar di program studi Hukum Ekonomi Syariah" ditolak .

iv) Hipotesis Biaya

Berdasarkan hasil Keputusan secara parsial bahwa, pengaruh biaya pendidikan terhadap keputusan siswa untuk belajar di program studi HES, nilai thitung 4,671 diperoleh dengan tingkat signifikansi 0,000. Oleh karena nilai signifikansi $<0,05$, dapat disimpulkan bahwa variabel gambar tidak mempengaruhi keputusan siswa, sehingga hipotesis pertama yang menyatakan "Biaya berpengaruh positif terhadap keputusan siswa untuk belajar di program studi Hukum Ekonomi Islam" diterima.

v) Hipotesis Prospek

Berdasarkan hasil keputusan secara parsial bahwa pengaruh Prospek pada keputusan siswa untuk belajar di program studi HES, t hitung 1,050 diperoleh dengan tingkat signifikansi 0,297. Karena nilai signifikansi> 0,05, dapat disimpulkan bahwa variabel prospek tidak mempengaruhi keputusan siswa, sehingga hipotesis pertama yang menyatakan "Prospek memiliki efek positif pada keputusan siswa untuk belajar di program studi Hukum Ekonomi Islam" ditolak. 
c) Uji Simultan (F)

Tes simultan digunakan untuk menentukan apakah variabel independen yaitu citra, biaya dan prospek program studi secara bersama-sama mempengaruhi variabel dependen, yaitu keputusan siswa untuk menempuh pendidikan di program studi Hukum Ekonomi Syariah. Berdasarkan hasil perhitungan simultan pengaruh ketiga variabel independen pada taraf signifikansi 5\% diperoleh Fhitung 7,564 dengan signifikansi 0,000.

\begin{tabular}{|c|c|c|c|c|c|c|}
\hline \multicolumn{7}{|c|}{ ANOVA $^{a}$} \\
\hline Model & & Sum of Squares & df & Mean Square & $\mathrm{F}$ & Sig. \\
\hline \multirow[t]{3}{*}{1} & Regression & 124,284 & 3 & 41,428 & 7,564 &, $000^{\mathrm{b}}$ \\
\hline & Residual & 361,487 & 66 & 5,477 & & \\
\hline & Total & 485,771 & 69 & & & \\
\hline
\end{tabular}

a. Dependent Variable: Keputusan

b. Predictors: (Constant), Prospek, Biaya, Citra

Oleh karena nilai signifikansinya kurang dari 0,05, itu berarti citra, biaya, dan prospek program studi secara bersamaan mempengaruhi keputusan siswa untuk mengambil pendidikan di program studi Hukum Ekonomi Islam, sehingga hipotesis keempat dalam penelitian ini diterima.

\section{Kesimpulan}

Berdasarkan data yang diperoleh dari hasil penelitian, kesimpulan yang dapat dikemukakan dalam penelitian ini adalah:

1. Pengaruh gambar pada keputusan mahasiswa untuk belajar di program studi HES, diperoleh thitung $-1,127$ dengan tingkat signifikansi 0,264 . Oleh karena nilai signifikansi $>0,05$, dapat disimpulkan bahwa variabel citra tidak berpengaruh pada keputusan mahasiswa, oleh karena itu hipotesis pertama yang menyatakan "Citra memiliki pengaruh positif terhadap keputusan siswa untuk belajar di program studi Hukum Ekonomi Syariah" ditolak.

2. Pengaruh biaya pendidikan pada keputusan siswa untuk belajar di program studi HES, diperoleh thitung 4,671 dengan tingkat signifikansi 0,000. Oleh karena nilai signifikansi $<0,05$, dapat disimpulkan bahwa variabel gambar tidak mempengaruhi keputusan siswa, sehingga hipotesis pertama yang menyatakan "Biaya berpengaruh positif terhadap keputusan siswa untuk belajar di program studi Hukum Ekonomi Islam" diterima.

3. Pengaruh Prospek terhadap keputusan siswa untuk belajar di program studi HES, diperoleh thitung sebesar 1,050 dengan tingkat signifikansi 0,297. Karena nilai signifikansi> 0,05, dapat disimpulkan bahwa variabel prospek tidak mempengaruhi keputusan siswa, sehingga hipotesis pertama yang menyatakan "Prospek memiliki efek positif pada keputusan siswa untuk belajar di program studi Hukum Ekonomi Islam" ditolak.

4. Karena nilai signifikansi kurang dari 0,05, itu berarti bahwa citra, biaya, dan prospek program studi secara bersamaan mempengaruhi keputusan siswa untuk mengambil pendidikan di program studi Hukum Ekonomi Islam, sehingga hipotesis keempat dalam penelitian ini diterima . 
Berdasarkan hasil diskusi dan kesimpulan dalam penelitian ini, beberapa saran dapat dibuat termasuk:

1. Citra dan prospek program studi tidak memiliki pengaruh positif dan signifikan terhadap keputusan siswa untuk mengambil pendidikan di program studi Hukum Ekonomi Syariah, oleh karena itu program studi Hukum Ekonomi Syariah harus meningkatkan citra dan reputasi Syariah Program studi Hukum Ekonomi.

2. Biaya memiliki dampak positif dan signifikan terhadap keputusan siswa dalam mengejar pendidikan di program studi Hukum Ekonomi Syariah, untuk itu STAIN Sultan Abdurrahman Kepulauan Riau selalu mempertahankan biaya ini sehingga lebih banyak siswa dalam program studi Hukum Ekonomi Syariah.

\section{A. Referensi}

Alma, Buchari. 1992. Manajemen Pemasaran dan Pemasaran Jasa. Badung: Alfabeta.

Cooper dan Emory. 1998. Metode Penelitian Bahasa. Jakarta: Erlangga.

Gozali, Imam. 2011. Aplikasi Analisis Multimedia dengan Program IBM SPSS 19. Semarang: UNDIP.

Gronross, Cristian. 1990. Service Management and Marketing: Managing Moment of Truth in Service Competitor. Maxwell Macmillan International Edition: Lexing Book.

Gunawan, Fifi. Et.al. 2005. Persepsi Kualitas Pendidikan Fasilitas dan Staf pengajar di Fakultas Ekonomi Universitas Kristen Petra Surabaya. Jurnal Manajemen dan Kewirausabaan. Vol 7. No. 2, September 2005: 113-124.

Gunawan, Yuliana. 2004. Analisis Faktor-Faktor yang mempengearuhi Keputusan Peminat untuk Memilih Jurusan Akuntansi Universitas Kristen Maranata Bandung. Jurnal Ilmiah Akuntansi. November 2004, Vol. 4, No.1: 39-48.

Handayani, Nur. 2006. Perbedaan Keputusan Mahasiswa dalam Memilih STIE di Jawa Timur. Jurnal Ekuitas, Vol. 11, No.3. September 2007:321-348.

Kinnear, Thomas dan Taylor James. 1987. Riset Pemasaran. Jakarta: Erlangga.

Kotler dan Karen F.A. Fox. 1995. Strategic Marketing for Education Instruction. Second Edition: PrenticeHall Inc.

Lubis, Arfan Ikhsan. 2010. Akuntansi Keperilakuan. Jakarta: Salemba Empat Edisi 2.

Maholtra, Naresh. 2004. Riset Pemasaran Pendekatan Terapan. Jakarta: Gramedia.

Nawawi, H. Hadari. 2001. Perencanaan SDM: Untuk Organisasi Profit yang Kompetitif. Yogyakarta: Gadjah Mada University Press.

Rosita, Jenny. 2009. Faktor-faktor yang mempengaruhi Mahasiswa dalam Mengambil Keputusan Memilih Universitas X di Surabaya. Jurnal Ekesekutif, Volume 6 Nomor 2, Juni 2009: 343-351.

Soedarmayanti dan Syarifudin. 2002. Metode Penelitian. Bandung: Mandar Maju.

Tanjak: Jounal of Education and Teaching, Vol. 1, No. 1, 2020 
Supranto, J. 1997. Metode Riset Aplikasinya dalam Pemasaran. Jakarta: Rineka Cipta.

Suharsono, Puguh. 2009. Metode Penelitian Kuantitatif untuk Proses Bisnis: Pendekatan Filosofi dan Praktis. Jakarta: Indexs.

Suryani, Tatik. 2007. Perilaku Kosumen: Implikasi Pada Strategi Pemasaran. Yogyakarta: Graha Ilmu.

Sukirno, Sadono. 1995. Pengantar Teori Makro Ekonomi. Jakarta: PT Raja Grafindo.

Suryani, Dian. 2001. Analisis Fktor-faktor yang Mempengaruhi Performa Mahasiswa Pada Mata Kuliah Pengantar Akuntansi. Skripsi. Yogyakarta: Universitas Gadjah Mada. 